\title{
Study on Changes of College English Teaching Method and Redefinition of Teachers' Roles in the Computer Network Environment
}

\author{
https://doi.org/10.3991/ijet.v12.i08.7138 \\ Bin Wang \\ Jilin Institute of Chemical Technology, Jilin, China \\ 28285734 @qq.com
}

\begin{abstract}
Through interviews and induction, this paper attempts to discuss the importance of college English teaching methods in the teaching process under the network context and point out issues like teachers' inadequate awareness and abilities of collecting network resources and information and insufficient background monitoring on students' study activities. Based on this, this paper proposes that college English teachers should free their minds, change their views and improve their network operation skills to know more about students' study activities and update their knowledge bases to improve their own quality so as to redefine their roles under the network context.
\end{abstract}

Keywords—network context; college English teaching; teachers' roles; teaching method changes

\section{Introduction}

With the rapid development of world economic integration, the demand for English communication is increasing in various sectors. In order to facilitate English learning many advanced technologies and tools have been applied, such as network computer tools. At present, network has been widely applied in college English teaching, and has attracted the attention of many scholars. This paper studies the changes of college English teaching methods and the redefinition of teachers' roles under the network context and proposes suggestions based on the advantages and disadvantages of network [1]. Under the network-based teaching model, college English teachers should redefine their roles, and make full use of computer and network tools to improve their teaching effect so as to lay a good foundation for the educational reform.

In the research, by consulting a lot of literature, doing interviews and making summaries and induction, this paper analyzes the functions that college English teachers should exert under this teaching context, discusses the roles they can play, such as the designer of network-based teaching activities, evaluator of learning results and collector of learning information, and suggests that teachers should actively play these functions and roles to improve their English teaching effects [2]. However, under the current situation, due to various reasons, most college English teachers still 
lack the awareness of collating network resources and information, fail to conduct sufficient monitoring and management on students' English learning status, and are inexperienced in network-based teaching, and as a result, the actual teaching effects are not good. In addition, some teachers do not know students' learning activities well and fail to update their own knowledge bases, so it is necessary to improve their performance in these areas [3-4]. Many college English teachers are not clear about their roles in the network-based teaching mode, which has affected their teaching effects; therefore, they need to change their traditional views, constantly improve their network operation skills, and update their knowledge bases so as to meet the new teaching requirements and properly redefine their roles in teaching.

\section{Roles of Teachers in Traditional College English Teaching}

In the long development process of Chinese civilization, a large number of outstanding achievements have been made in human civilization. While these achievements were inherited, many unique teaching methods and patterns were also developed. The educational ideas and philosophies summarized by some outstanding scholars have been handed down for thousands of years and are widely adopted in the current society. Ancient scholars also expounded teachers' duties and functions. For example, Han $\mathrm{Yu}$ believed that "teachers are the ones who propagate the doctrine, impart professional knowledge and resolve doubts", indicating that teachers should have three functions - "preaching, teaching and resolving doubts", which became a widely accepted opinion on teachers' functions and roles. However, in the current English teaching process in China, teachers are still playing a dominant role, while students only passively receive knowledge. This traditional teaching model gradually fails to meet the current development needs, and relevant national authorities need to make some changes [5-7]. At the same time, there are many new English teaching models adopted internationally. For example, the grammar-translation method is being introduced to our college English teaching activities. Through detailed analysis, we can see that a traditional college English teacher has the following main roles, as shown in Fig. 1.

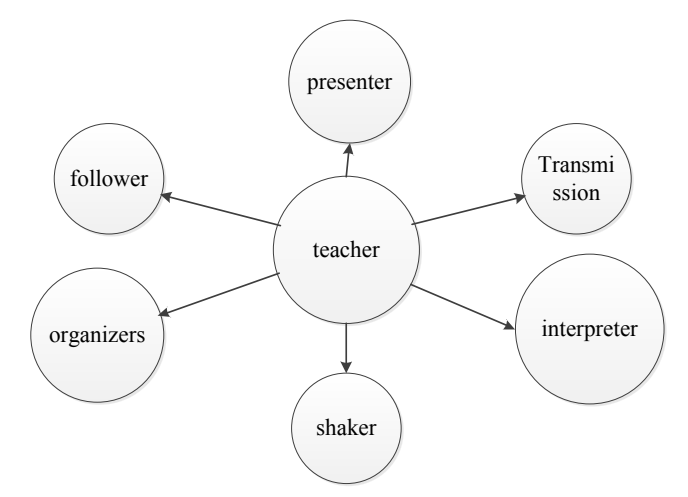

Fig. 1. College English Teachers' Roles in Traditional Teaching 


\subsection{Follower and presenter of textbooks}

Under the traditional teacher-centered teaching model, what to teach depends largely on textbooks, and teachers are just the followers and presenters of these textbooks. Courses are only designed on the basis of textbooks and even teaching activities are arranged based thereon. Under this teaching model, college English teachers usually go by the book without making any changes to the contents, showing little initiative and flexibility in teaching. In addition, at the traditional teaching times, internet was not popularized, so it was very difficult for college English teachers to find real English dialogue materials. Teachers had to rely on textbooks and students also studied mainly from these books [8]. Of course, this teaching model has its merits - teachers understand exactly what to teach and students know what to learn. However, under this model, their source of knowledge is very limited, hindering them from knowing more.

\subsection{Transmitter and explainer of knowledge}

Under this teaching model, teachers play a leading role in class. They not only transmit and explain knowledge, but also provide supervision and control over student's learning. Usually, teachers write what they are going to teach on the blackboard, and students passively receive information by looking at the blackboard and reading textbooks. In this way, students do not think by themselves, nor do they take initiative in learning [9]. However, in college, English teaching requires students to have independent learning abilities, and focuses on the comprehensive training covering listening, speaking, reading and writing. Unfortunately, the only opportunities students have to train their listening and speaking skills are the face-to-face classroom teaching from teachers. Therefore, under this teaching model, students are always in a passive situation. They are weak in active thinking and exploration and seldom ask teachers questions.

\subsection{Organizer of classroom activities}

English teaching focuses on the training practical skills; therefore, teachers have to provide a lot of training in class for students on listening, speaking, reading and writing. However, under the traditional teaching model, teachers have limited teaching methods and tools - mainly through blackboards, chalks, tape recorders and PowerPoint slides - to transmit information, which is inefficient and does not well achieve the above teaching purposes [10]. Although students can learn basic knowledge and get familiar with basic concepts and principles from writings on the blackboard and slides, most of them do not really participate in the classroom activities and are still passive receptors of knowledge. Besides, the traditional classroom cannot create a good language environment for English learning, so a lot of language practices cannot be done in class, greatly affecting the achievement of English teaching objectives [11]. Under the traditional teaching model, students practice English mainly by creating hypothetical scenarios and carrying out some role-plays. But due to lack of a real 
vivid environment, these practices are not quite effective in consolidating students' knowledge system, nor do they leave deep impression in students' mind.

\section{Issues with College English Teachers' Roles Under The network context}

\subsection{Inadequate management on network resources}

From the analysis, we can see that traditional college English teachers are not playing proper roles in their teaching, nor do they serve well as information collectors and collators. They tend to ask students to search information not necessarily relevant to English learning indiscriminately, believing it to be the main English teaching approach under the network environment, and neglect their own roles and duties in teaching. Most students try to search as much information as they can on the Internet to study English, simply presuming that the more information they get, the better they accomplish their learning tasks. In fact, teachers seldom analyze and sort the information collected, nor do they rationally arrange teaching schedules based on students' learning progress and foundation. Thus they fail to serve as good network information analyzers [12].

\subsection{Insufficient supervision and control over students' learning activities}

Statistics show that many college English teachers are not quite clear about how to properly use network in their teaching and simply think that network-based teaching is to provide students with absolute freedom and give no intervention and guidance in their study. As a result, students are not guided or controlled in their learning activities, making it difficult for teachers to achieve their teaching objectives. Therefore, college English teachers should understand their roles as supervisors and controllers and play them well in their actual teaching activities. At the same time they should also be aware that, though they no longer play the dominant role in providing knowledge and resources, students still cannot study without their guidance. Under this network-based teaching model, teachers should be neither too hard nor too soft on students' study; instead, they should conduct appropriate supervision and control. Teachers should be clear about their new roles, give students enough room so that students can play a leading role in their learning activities, and at the same time fulfill their own duties as teachers.

\subsection{Teachers' quality falling below the requirements of the information age}

Under the traditional teaching model, teachers are the authority of knowledge they call all the shots in everything, which has misled many teachers in understanding their roles in teaching. For example, not a few college English teachers think that they are right about everything regarding English, and that they do not need to refer to the knowledge posted on the Internet. In fact, such wrong ideas have affected their teach- 
ing activities. Currently, in this age of network information explosion, knowledge on the Internet is changing from day to day, and new knowledge and concepts are emerging constantly, many of which are what teachers are not aware of or familiar with. Therefore, it is very necessary for them to update their own knowledge bases. However, some teachers can be stubborn and resistant to network, and thus they seldom take an initiative to learn things from the Internet. In addition, a lot of college English teachers are not proficient in using network technologies and computer, hindering them from smoothly communicating with students online (as shown in Fig. 2).

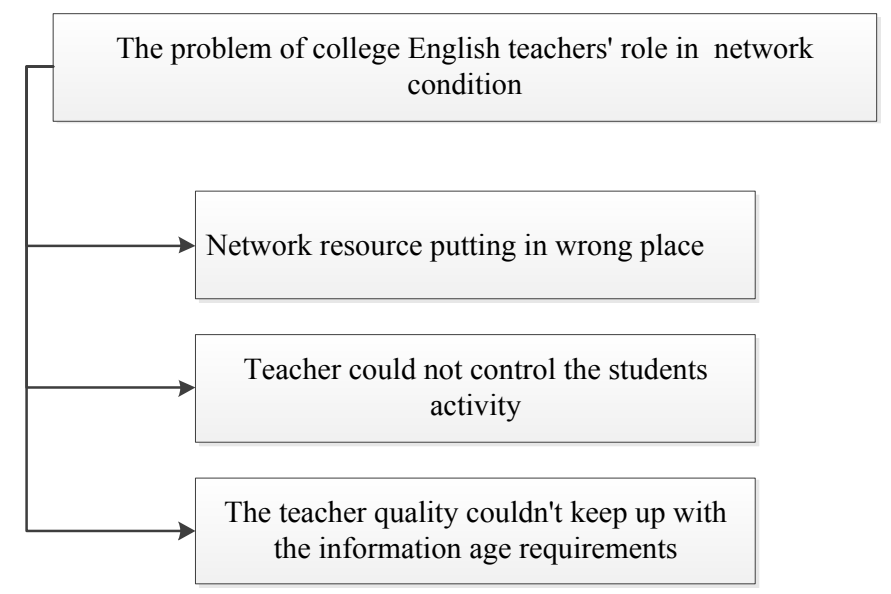

Fig. 2. Analysis of the Issues in College English Teacher's Role Defining under The network context

\section{$4 \quad$ Factors Affecting College English Teachers' Role Redefining in the Network Context}

\subsection{Inadequate awareness and abilities of collating network resources and information}

There is a mass of information on the Internet that students can access and search, and most of this information is highly interactive. The network-aided teaching approach can use this information and resources efficiently and provide a solid information base for college English teaching. In addition, college English teachers can also integrate online educational resources as needed and update these resources in a flexible manner so as to meet teaching needs. In the network context, there have also been a lot of changes in what to teach and how to teach. Many new teaching tools have been applied, diversifying the language teaching forms and better meeting student's learning needs. Therefore, teachers should be aware that they need to integrate network resources more and get familiar with relevant network operations and applications so as to allow more efficient sharing of educational resources and lay a good foundation for teaching improvements. 


\subsection{Lack of motives to update teachers' knowledge bases}

English resources and information on the Internet change every day. By using network tools, we can easily access the latest English news and download multifunctional teaching software and a wide range of English learning video resources as needed. These resources are abundant and updated much more frequently than books and magazines. However, influenced by the traditional view, many college English teachers are reluctant to spend time in learning new knowledge, and rarely take the initiative to update their own knowledge bases, and as a result, they start to fall behind the times. Through analysis, we can see that the factors that affect college English teachers' role redefining in the network context are as follows, shown in Fig.3.

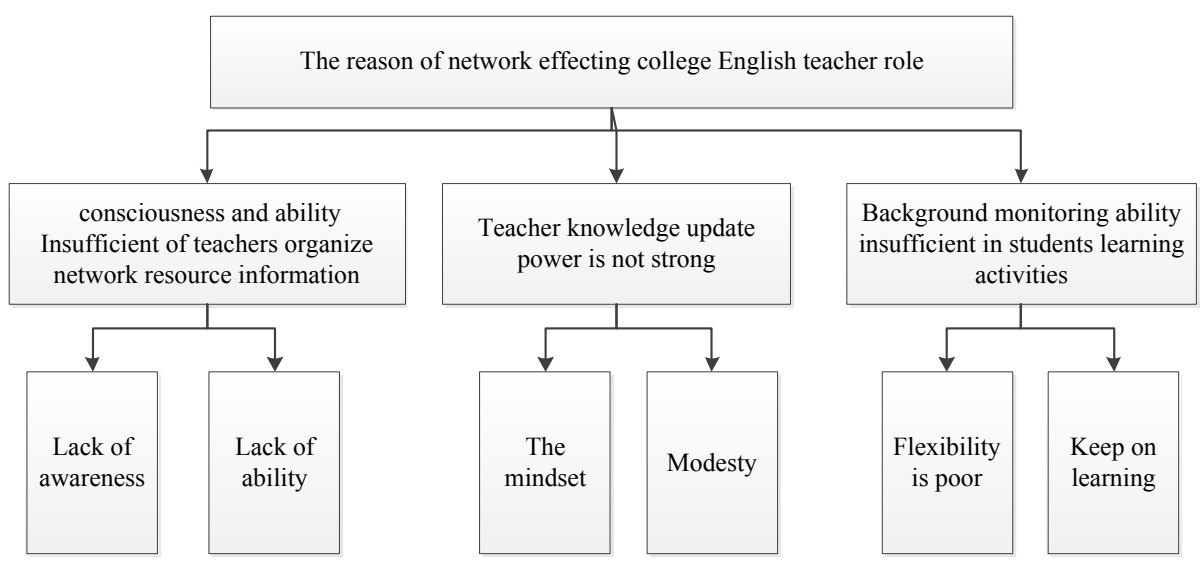

Fig. 3. Factors Affecting College English Teachers' Role Redefining in the Network Context

\section{How to Play the New Roles of College English Teachers in the Network Context}

\subsection{Change the traditional teaching ideas}

At present, information and multimedia technologies are being widely applied in various sectors and fields, including college English teaching. For example, many colleges have begun to use network and computer tools in providing English pronunciation, listening, speaking and reading, which has changed a lot in the college English teaching model. As a result, college English teachers have to refine their roles in teaching, and actively use network-based multimedia tools. With the rapid development of network computer technologies, it has become quite easy to present real sounds and images with the help of computer, providing ideal conditions for language teaching. Network and computer will bring many advantages and conveniences to college English teaching. Therefore, teachers need to change their traditional views and embrace the knowledge and resources that network brings so that they can adjust their teaching methods to better meet the new teaching requirements. 


\subsection{Improve network operation skills and effectively control students' learning activities}

At present, most colleges and universities have begun to use network tools to carry out English teaching, which has put forward higher requirements for college English teachers, like proficient network operation skills and better course designing, monitoring and organizational abilities. In addition, under the network-based teaching model, college English teachers should actively update their own knowledge bases and strengthen their own application and network operation skills so as to use information and resources flexibly to carry out related teaching activities. They are also required to efficiently collect teaching resources through network, enrich their teaching contents, design appropriate teaching schedules, properly supervise the learning status of students and at the same time mobilize students' learning initiatives and practical abilities to lay a good foundation for their comprehensive English skills.

\subsection{Update the knowledge base and improve the overall quality of faculty teams}

With the current reform of college English teaching, teachers' quality starts to show its importance in college English teaching activities and is having significant impacts on the effectiveness of such reform. Therefore, teachers should constantly update and expand their own knowledge bases, and improve their comprehensive abilities. The Internet is undoubtedly the main way for them to update their knowledge bases. With the help of advanced network technologies, college English teachers should take the lead in learning and updating their knowledge in order not to be left behind and at the same time improve their quality in various aspects to better meet the current development needs (Fig. 4).

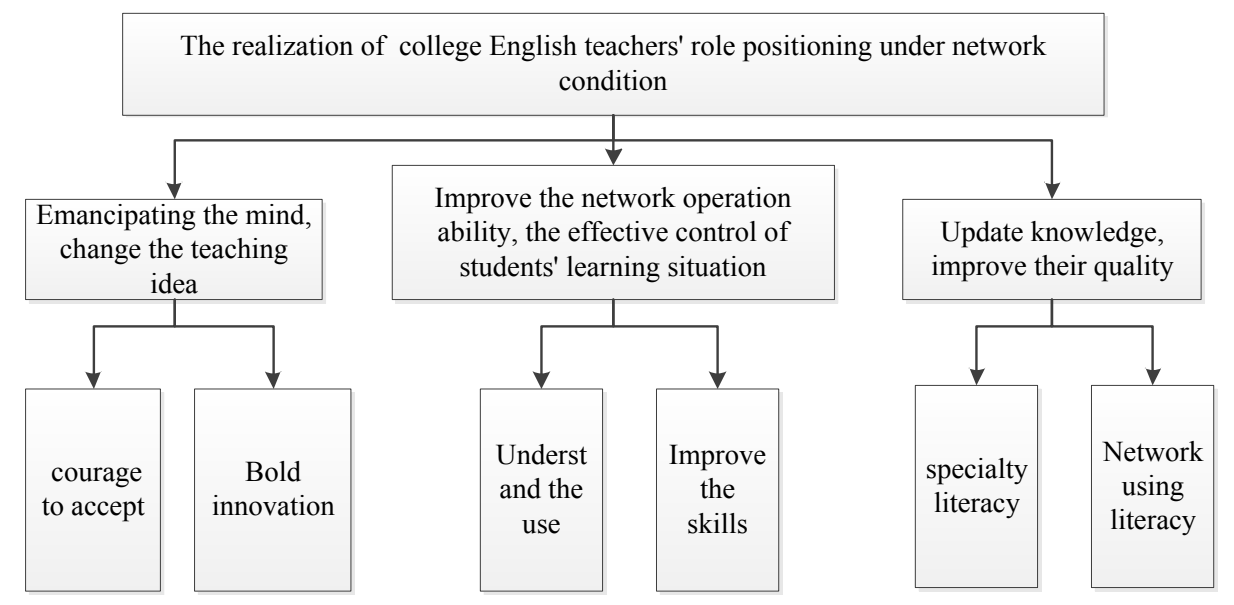

Fig. 4. How to Play the New Roles of College English Teachers in the Network Context 


\section{Conclusions}

Under the network context, significant changes have taken place in the college English teaching model, displaying obvious characteristics of the times. These changes have redefined the roles of college English teachers in teaching. To well play these new roles, teachers have to constantly update their own knowledge bases and improve their overall quality and abilities. At the same time, they need to positively face the challenges and opportunities ahead and make full use of various constructivism education theories and methodologies to better play their roles in English teaching activities. This paper mainly studies the redefined roles of college English teachers under the current network context, and thinks that these roles include network knowledge and information collector, teaching activity designer and teaching effect evaluator. In addition, this paper also analyzes the current issues in the role defining of college English teachers and the reasons behind these issues, and proposes appropriate suggestions in the hope of providing some reference and guidance in improving college English teaching effects.

\section{$7 \quad$ References}

[1] Chang, C.C., Tseng, K.H., Tseng, J.S. (2011). Is single or dual channel with different english proficiencies better for english listening comprehension, cognitive load and attitude in ubiquitous learning environment?. Computers \& Education, 57(4), 2313-2321. https://doi.org/10.1016/j.compedu.2011.06.006

[2] Mai H. (2001). The impact of affective factors on the teaching of english listening in colleges. Smart Materials \& Structures, 10, 2143-2145.

[3] Hsu, C.K., Hwang, G.J., Chang, Y.T., Chang, C.K. (2013). Effects of video caption modes on english listening comprehension and vocabulary acquisition using handheld devices. Educational Technology \& Society, 16(1), 403-414.

[4] Hwang, W.Y., Huang, Y.M., Shadiev, R., Wu, S.Y., Chen, S.L. (2014). Effects of using mobile devices on english listening diversity and speaking for efl elementary students. Australasian Journal of Educational Technology, 30(30), 503-516. https://doi.org/10.14742/ajet.237

[5] Yamada, M., Kitamura, S., Shimada, N., Utashiro, T., Shigeta, K., Yamaguch, E. (2011). Development and evaluation of english listening study materials for business people who use mobile devices: a case study. Calico Journal, 29(1), 44-66. https://doi.org/10.11139/ cj.29.1.44-66

[6] Olea, J., Abad, F.J., Ponsoda, V., Barrada, J.R., Aguado, D. (2011). Ecat-listening: design and psychometric properties of a computerized adaptive test on english listening. Psicothema, 23(4), 802-7.

[7] Bidabadi, F.S., Yamat, H. (2012). The relationship between english listening proficiency levels and learning styles. Gema Online Journal of Language Studies, 12(4), 1041-1055.

[8] Chen, H. (2011). Brief analysis of strategies to improve english listening comprehension competence among non-english undergraduate students. Asian Social Science, 7(12). https://doi.org/10.5539/ass.v7n12p68

[9] Lei, L.H. (2006). The application of schema theory in college english listening teaching. Theory \& Practice in Language Studies, 26, 282-288. 
[10] Hsu, C.K., Hwang, G.J., Chang, C.K. (2014). An automatic caption filtering and partial hiding approach to improving the english listening comprehension of efl students. Educational Technology \& Society, 17(2), 270-283.

[11] Lee, M., Yorick, W. (2011). Conversational implicature in english listening comprehension. Journal of Language Teaching \& Research, 2, 103-121.

[12] Wong, J. (2005). English listening courses: a case of pedagogy lagging behind technology. Electronic Journal of Foreign Language Teaching, 2, 25-43.

[13] Xu, X. (2013). Empirical study on the english listening learning anxiety. Theory \& Practice in Language Studies, 3(8). https://doi.org/10.4304/tpls.3.8.1375-1380

\section{Author}

Bin Wang is a lecturer in Jilin Institute of Chemical Technology, mainly engaged in Intercultural Communication and English Teaching. (28285734@qq.com)

Article submitted 13 May 2017. Published as resubmitted by the authors 20 June 2017. 